\title{
The Effects of Adipose Tissue-Derived Mesenchymal Stem Cell Transplantation During the Acute and Subacute Phases Following Spinal Cord Injury
}

\author{
Yavuz ARAS ${ }^{1}$, Pulat Akin SABANCI ${ }^{1}$, Serdar KABATAS ${ }^{2}$, Gokhan DURUKSU ${ }^{3}$, Cansu SUBASI ${ }^{4}$, Mine ERGUVEN ${ }^{5}$, \\ Erdal KARAOZ ${ }^{4}$ \\ ${ }^{1}$ Istanbul University, Istanbul School of Medicine, Department of Neurosurgery, Istanbul, Turkey \\ ${ }^{2}$ Reyap Hospital, Department of Neurosurgery, Tekirdağ, Turkey \\ ${ }^{3}$ Kocaeli University, Center for Stem Cell and Gene Therapies Research and Practice, Institute of Health Sciences, Department of Stem Cell, \\ Izmit-Kocaeli, Turkey \\ ${ }^{4}$ Liv Hospital, Center for Regenerative Medicine and Stem Cell Research \& Manufacturing (LivMedCell), Istanbul, Turkey \\ ${ }^{5}$ Istanbul Aydin University, Faculty of Health Sciences, Istanbul, Turkey
}

\section{ABSTRACT}

AIM: To investigate the effectiveness of rat adipose tissue-derived ( $r A T)$ mesenchymal stem cell (MSC) transplantation on the functional restoration and regeneration of spinal cord injury (SCI).

MATERIAL and METHODS: Six of 48 Wistar albino rats were sacrificed to obtain MSCs, and the remaining rats were divided randomly into six groups. $\mathrm{SCl}$ was performed using the clip compression method. The control and transplantation groups were injected with physiological saline and a rAT-MSC suspension at the injury sites, respectively. Each animal was evaluated using the Basso, Beattie and Bresnahan (BBB) rating system and sacrificed at 28 days post-injury period (p.i.). The regeneration process was evaluated based on immunostaining against $\beta 3$-tubulin, BDNF, CNTF, and CNPase.

RESULTS: rAT-MSC transplantation into the SCI site substantially improved the tissue regeneration and functional recovery $(p<$ 0.05). However, the rAT-MSC transplantation at 9 days p.i. was not more efficient on functional recovery than the transplantation immediately after injury. The expression of $\beta 3$-tubulin, BDNF and CNTF at the injury site indicated the potential for functional regeneration.

CONCLUSION: The adaptive nature of rat-MSCs enabled the remodulation and regeneration of the lesion site, decreasing the importance of transplantation time in the treatment of SCl.

KEYWORDS: Adipose tissue, Mesenchymal Stem cells, Spinal cord injury, Transplantation

ABBREVIATIONS: BBB scoring: Basso, Beattie and Bresnahan scoring, BDNF: Brain-derived neurotrophic factor, BFGF: Basic fibroblast growth factor, CNPase: 2',3'-cyclic-nucleotide 3'-phosphodiesterase, CNTF: Ciliary neurotrophic factor, DAPI: 4',6-diamidino-2-phenylindole, DMEM: Dulbecco's modified Eagle's medium, EGF: Epidermal growth factor, FBS: Fetal bovine serum, GFP: Green fluorescent protein, GFAP: Glial fibraillary acidic protein, L+T: Laminectomy and trauma, ms: Milliseconds, PFA: Paraformaldehyde, p.i.: Post-injury, rAT-MSCs: Rat adipose tissue-derived mesenchymal stem cells, SCI: Spinal cord injury, V: Volts. 


\section{INTRODUCTION}

The maximum recovery of spinal cord function has become a research hotspot in the treatment of spinal cord injury (SCl). Various cell transplantation techniques have been reported as possible treatments for $\mathrm{SCl}$ (11). Stem cell-based therapies promise some valuable strategies for functional recovery. Because transplanted mesenchymal stem cells (MSCs) have been shown to be effective for regeneration of the central nervous system after $\mathrm{SCl}$ in animal studies, MSC transplantation is considered an alternative treatment. Moreover, MSCs can be obtained safely elsewhere, such as the adipose tissue, and autologously transplanted. Thus, researchers use MSCs in addition to neural progenitor stem cells to obtain functional recovery after $\operatorname{SCl}(20,21)$.

In our previous report, bone marrow-derived MSCs (BMMSCs) were shown to be involved in successful functional regeneration following experimental $\mathrm{SCl}$ (14). Similarly, rat adipose tissue-derived mesenchymal stem cells (rAT-MSCs) were shown to express the early neurogenic markers GFAP, Nestin and c-Fos, indicating that the steps toward neurogenic differentiation occurred in chemical cocktail-supplemented media (4). Therefore, rAT-MSCs and rBM-MSCs have the potential to support the regeneration process directly or indirectly. A number of studies on different types of animal models and on human subjects have demonstrated functional recovery by MSCs $(1,6,10,12,18,19,27,29)$.

The aim of this study was to investigate the effects of rAT-MSC transplantation on the functional restoration, regeneration and volume of lesions in injured spinal cords at different time points. The neural differentiation capacities of rAT-MSCs delivered to the defect area at acute and subacute phases p.i. were analyzed, and the effects of rAT-MSC transplantation on the functional recovery of the injured spinal cord was evaluated.

\section{MATERIAL and METHODS}

\section{Animals and Experimental Design}

This study included 48 female, non-pregnant Wistar albino rats weighing 200-220 g. Initially, six of the rats were sacrificed, and their periperitoneal adipose tissue was removed to obtain MSCs. SCl was performed by cerebral vascular clipping (Yasargil Aneurysm Clip, FE691 K) with a 50 g/60 sec closing force after T10-11 total laminectomy. The remaining rats were divided into the following six groups ( $\mathrm{n}=7 /$ group): group 1 , only laminectomy was performed (L group-sham); group 2, laminectomy and trauma $(\mathrm{L}+\mathrm{T})$ were performed $(\mathrm{L}+\mathrm{T}$ group); group 3, L+T were performed, and physiological saline (PHS) was injected into the defect area ( $\mathrm{L}+\mathrm{T}+\mathrm{PHS} /$ acute group); group 4, L+T were performed, and MSCs were injected into the defect area ( $\mathrm{L}+\mathrm{T}+\mathrm{MSC}$ /acute group); group 5, $\mathrm{L}+\mathrm{T}$ were performed, and PHS was injected into the trauma site on the $9^{\text {th }}$ day p.i. ( $L+T+P H S /$ subacute group); and group $6, L+T$ were performed, and MSCs were injected into the defect area on the $9^{\text {th }}$ day p.i. ( $\left.L+T+M S C s / s u b a c u t e ~ g r o u p\right)$. The rats were sacrificed on the $28^{\text {th }}$ day after transplantation. This study was conducted in accordance with the Declaration of Helsinki. The experimental design and all procedures were approved by the Ethics Committee of Istanbul University .

\section{Isolation and Culture of rAT-MSCs}

rAT-MSCs were isolated and cultured as described previously (4). Briefly, rats $(n=6)$ were anesthetized by injection of 10 $\mathrm{mg} / \mathrm{kg}$ xylazine and $75 \mathrm{mg} / \mathrm{kg}$ ketamine. In total, $1-2 \mathrm{~cm}^{3}$ of periperitoneal adipose tissue was removed and enzymatically digested in Dulbecco's modified Eagle's medium (DMEM; Gibco Life Technologies, Paisley, UK) containing $0.075 \%$ collagenase 2 (Sigma-Aldrich, St. Louis, MO) at $37{ }^{\circ} \mathrm{C}$ for $60 \mathrm{~min}$. The cell suspension was filtered through a $70-\mu \mathrm{m}$ sieve (Becton Dickinson Labware, Franklin Lakes, NJ). To remove erythrocytes, the cells were resuspended in DMEM supplemented with $1 \%$ penicillin/streptomycin and $10 \%$ fetal bovine serum (FBS; standard culture medium) and were then centrifuged for $10 \mathrm{~min}$ at $1200 \mathrm{rpm}$. After 7 days of culture, the medium was replaced with fresh medium, which was subsequently replaced twice a week.

\section{Characterization of rAT-MSCs}

The isolated cells were cultured in FBS until the $3^{\text {rd }}$ passage. Then, the cells were examined for cell surface marker expression and their differentiation potential, the criteria of MSCs as defined by Bourin et al. (3). To confirm the phenotypic characteristics of the isolated cells, undifferentiated MSCs were first subjected to flow cytometric analysis using a FACSCalibur (BD Biosciences, San Jose, CA). The analysis was performed against the following antigens: CD29, CD45, CD54, CD90, and CD106 (BD Biosciences) as described previously (4). The in vitro studies of adipogenic, osteogenic, and neurogenic differentiations were performed according to the methods described previously (4).

To induce adipogenic differentiation, the cells were cultured in MesenCult MSC Basal Medium supplemented with $10 \%$ adipogenic supplement (StemCell Technologies Inc., Vancouver, BC, Canada) and 1\% penicillin/streptomycin for 3 weeks. Intracellular lipid droplets indicating adipogenic differentiation were confirmed by Oil Red O staining $(0.5 \%$ in methanol; Sigma-Aldrich, St. Louis, MO). For osteogenic differentiation, cells were cultured in DMEM supplemented with $0.1 \mu \mathrm{M}$ dexamethasone (Sigma-Aldrich), $0.05 \mu \mathrm{M}$ ascorbate-2-phosphate (Wako Chemicals, Richmond, VA), $10 \mathrm{mM} \beta$-glycerophosphate (Sigma-Aldrich), 1\% antibiotic/ antimycotic and $10 \%$ FBS. After four weeks, osteogenic differentiation was assessed by staining with $2 \%$ Alizarin red $\mathrm{S}(\mathrm{pH} 4.2)$ for $30 \mathrm{sec}$, followed by dehydration in pure acetone. To induce neurogenic differentiation, cells were cultured for 3-5 days in differentiation medium [DMEM supplemented with $0.5 \mathrm{mM}$ isobutylmethylxanthine, $10 \mathrm{ng} / \mathrm{ml}$ brain-derived neurotrophic factor (BDNF), $10 \mathrm{ng} / \mathrm{ml}$ epidermal growth factor (EGF), $10 \mathrm{ng} / \mathrm{ml}$ basic fibroblast growth factor (BFGF), $20 \%$ neural stem cell proliferation supplement (StemCell Technologies Inc.) and 1\% penicillin-streptomycin].

\section{GFP Labeling of MSCs}

The pGFP plasmid was obtained from Clontech (Palo Alto, $\mathrm{CA})$, amplified in $\mathrm{XL}-1$ strain of $E$. coli and purified using an 
endotoxin-free plasmid isolation kit (Qiagen). The plasmid was transfected into the target cells using a Neon Transfection System (Invitrogen, Carlsbad, CA). In total, $2 \times 10^{5}$ target cells were mixed with $1 \mu \mathrm{g}$ plasmid DNA in $10 \mu \mathrm{l}$ transfer buffer that was supplied with the transfection system kit (Invitrogen). The transfection parameters were adjusted to 1200 volts (V), 40 milliseconds (ms), and a single pulse. The transiently transformed cells were transferred into a tube containing 1 $\mathrm{ml}$ DMEM supplemented with $10 \%$ FBS. Following $48 \mathrm{~h}$ of incubation, the cells were selected with G418 (Gibco, $200 \mu \mathrm{g} /$ $\mathrm{ml}$ in media) for 6 weeks.

\section{Surgical Procedure}

The experiment was performed on 42 young female, nonpregnant Wistar albino rats (2 months old, 200-220 g). The skin was prepared for T10-11 spinal cord surgery, dorsal laminectomy, and injection to trauma site by shaving the dermal surface of the related regions with a hair razor and by cleaning the skin with antibacterial soap, followed by betadine, and finally $70 \%$ ethanol (5). After an overnight fast with unrestricted access to water, all rats were anesthetized with intramuscular ketamine and xylazine. One level laminectomy encompassing the caudal end of the T10 vertebra was performed under a dissection stereomicroscope. For the SCl groups, T10-T11 injury was induced by clipping (vulnerating energy of $50 \mathrm{~g} /$ $\mathrm{cm} / 60 \mathrm{sec}$ ). The animals were left to recover for $12 \mathrm{~h}$ after surgery in a clean, partially heated cage.

\section{Cell Transplantation}

In total, $5 \mu \mathrm{l}$ of rAT-MSCs stock containing $3 \times 10^{5}$ cells were transplanted over a period of 5 minute into the injured spinal cord via a Hamilton syringe (Hamilton, Reno, NV), which was connected to a syringe pump (KD Scientific Inc., Holliston, MA). The same method was used to deliver $5 \mu \mathrm{l}$ PHS into the injured spinal cords of the rats in groups 3 and 5 . The needle was inserted into the spinal cord at the trauma site approximately $1 \mathrm{~mm}$. and kept 10 minutes after injection of PHS or rAT-MSCs. The pipette was advanced from the dorsal surface and then withdrawn slowly to prevent leakage from the injection site. The needle was removed $10 \mathrm{~min}$ after transplantation. The muscle, subcutaneous, and skin layers were closed in layers, and bladder expression was allowed to continue. The animals were assigned new identification codes after transplantation to ensure blind evaluation of behavioral analysis.

\section{BBB Scoring of Functional Tests}

Functional tests were scored using the Basso, Beattie and Bresnahan (BBB) locomotor rating scale at pre-surgery and on the $1^{\text {st }}, 7^{\text {th }}, 14^{\text {th }}, 21^{\text {st }}$, and $28^{\text {th }}$ days p.i. Two independent blinded examiners observed and video-recorded the hindlimb movements and assessed the animal's locomotor function (2).

\section{Tissue Harvesting Histopathological and Immunohistochemical Examination}

Rats were anesthetized with a mix of ketamine $(75 \mathrm{mg} / \mathrm{kg}$, i.p.) and xylazine (20 $\mathrm{mg} / \mathrm{kg}$, i.p.). The animals were perfused transcardially with saline $(150 \mathrm{ml} / \mathrm{per}$ animal), followed by $4 \%$ neutral buffered paraformaldehyde (PFA; $200 \mathrm{ml} /$ per animal) in
$0.1 \mathrm{~mol} / \mathrm{L}$ PBS $(\mathrm{pH} 7.4)$ before the removal of relevant tissue. Then, a $1.0 \mathrm{~cm}$ segment of the spinal cord encompassing the injury site was removed. The tissues were post-fixed in $4 \%$ PFA in PBS for approximately $24 \mathrm{~h}$ and then embedded in paraffin. Longitudinal $5-\mu \mathrm{m}$ thick serial sections were taken from each paraffin embedded spinal cord sample.

To perform cell tracing after the GFP-labeled rAT-MSCs were injected, an immunofluorescence double staining protocol was performed on the paraffin-embedded tissues. Slides were deparaffinized with two changes of xylene for $5 \mathrm{~min}$ each and then rehydrated in a series of graded alcohol solutions of 100,90 , and $80 \%$. Antigen retrieval was performed on the slides using a steamer-citrate buffer antigen retrieval method. Endogenous peroxidase activity was blocked by incubating the slides in fresh $3 \% \mathrm{H}_{2} \mathrm{O}_{2}$ in PBS buffer. Nonspecific staining was blocked with a mixture of two different sera at $1.5 \%$ in PBS for $30 \mathrm{~min}$ at room temperature (RT). The sections were incubated for $1 \mathrm{~h}$ at RT with the following primary antibodies: anti-GFP antibody (sc-9996; Santa Cruz, Heidelberg, Germany), vimentin (sc-7557; Santa Cruz), $\beta$ 3-tubulin (sc-69965; Santa Cruz), BDNF (sc-20981; Santa Cruz), CNTF (sc-1912; Santa Cruz) and CNPase (MS-349-R7; Thermo Scientific, Rockford, IL). The sections were incubated in a mixture of two fluorescence-conjugated secondary antibodies, which included goat anti-mouse FITC (sc-2010), donkey anti-goat TR (sc-2783), and goat anti-mouse TR (sc2781) at a dilution of 1:50 in PBS for 30 min at RT. The sections were mounted with mounting medium containing DAPI (Santa Cruz Biotechnology). Then, the mounted cells were examined under a fluorescence microscope (Leica DMI 4000B, Wetzlar, Germany).

\section{Apoptosis Detection}

Terminal dUTP nick-end labeling (TUNEL) was performed using an ApopTAG Fluorescein In Situ Apoptosis Detection Kit (Millipore, Billerica, MA) according to the manufacturer's directions. Briefly, spinal cord sections from each group were fixed in 4\% PFA. Then, the samples were incubated with terminal deoxynucleotidyl transferase enzyme, followed by incubation with anti-digoxigenin conjugate. Mounting medium containing DAPI (Santa Cruz Biotechnology) was added as a nuclear counter-stain. Each section was scanned and counted for positive green fluorescent cells in the retinal layers, which indicated apoptosis.

\section{Statistical Analyses}

All statistical analyses were performed using SPSS 10.0 (SPSS Inc., Chicago, IL, USA). Data were analyzed using Student's t test. Differences between the experimental and control groups were regarded as statistically significant when $p<0.05$.

\section{RESULTS}

\section{Characterization of rAT-MSCs}

Non-adherent small cells presented in the primary culture were gradually depleted in further passages. A pure population of fibroblast-like, spindle-shaped cells appeared after three passages. The expression of MSC markers was 

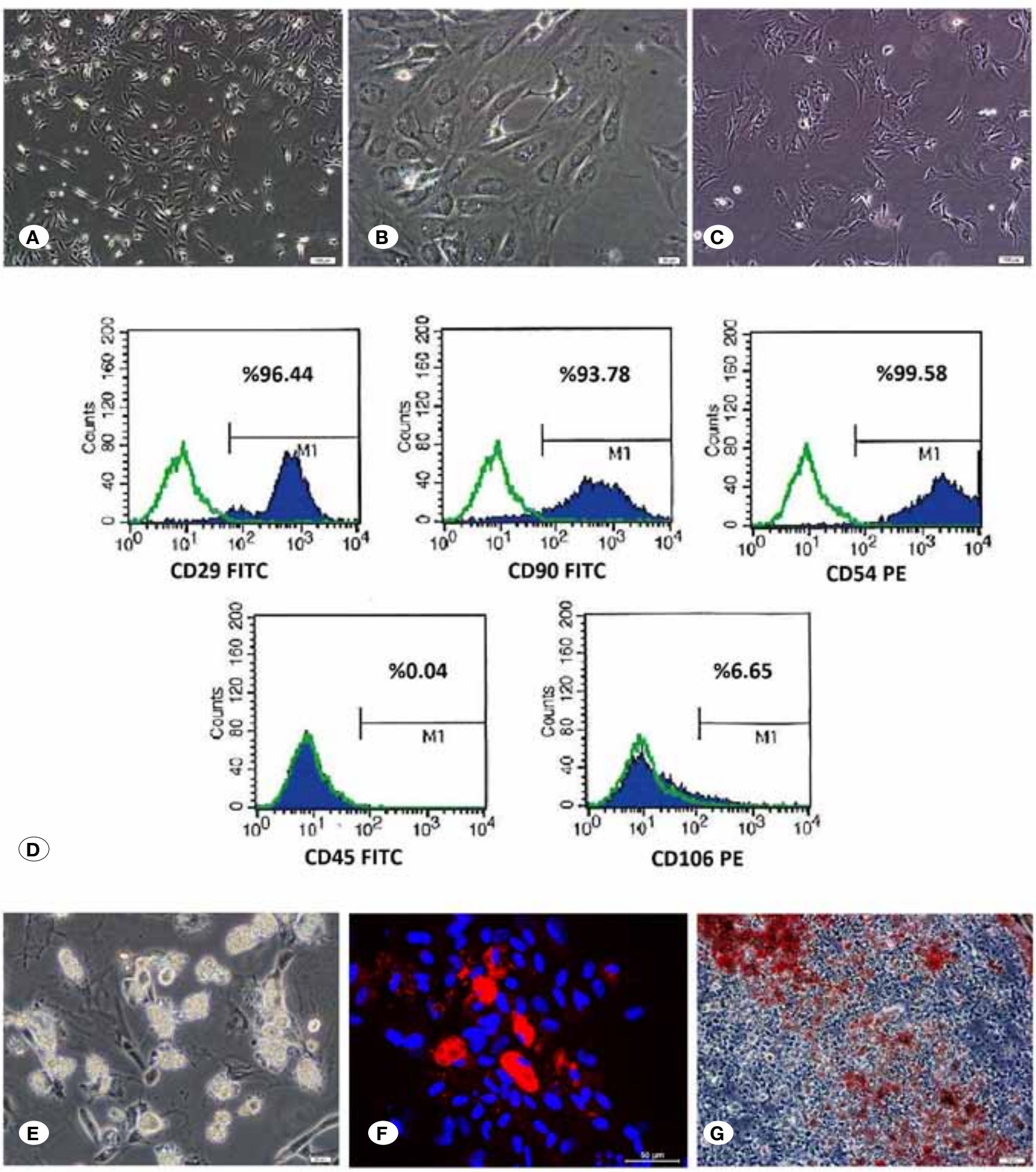

Supplementary Data 1: A-C) Isolated cells from rAT-SCs, distributed sparsely on the culture flasks and displayed a mostly fibroblastlike, spindle-shaped morphology during the early days of incubation. The small colonies (A: P0-4th day ,100 $\mu \mathrm{m}$, B: P0 4th day, $20 \mu \mathrm{m})$ reached monolayer confluence within 10-12 d. In the later passages, most of these MSCs exhibited a large, flattened, or fibroblast-like morphology (C: P3-3rd day,100 $\mu \mathrm{m}$ ) D) Immunophenotypic properties of rAT-SCs by flow cytometry. Pre-defined markers that specify MSCs were used to define the characteristics of cultured cells. rAT-SCs expressed all mesenchymal stem cell markers including CD29, CD54 and CD90; but not CD106 and CD45 In vitro differentiation of rAT-SCs. E-F) Adipogenic differentiation was identified by the formation of neutral lipid vacuoles (stained with oil red) in cultures (scale bars E) $20 \mu \mathrm{m}, \mathrm{F}) 50 \mu \mathrm{m}$ ). G) After the osteogenic induction, mineral nodules were stained positive with Alizarin red S staining (Scale bar $50 \mu \mathrm{m}$ ). 
analyzed by flow cytometry, revealing cells that were positive for CD29, CD54 and CD90 and negative for CD45 and CD106 (Supplementary Data 1). The multipotency of the isolated cells was determined by adipogenic, neurogenic and osteogenic differentiation. After three weeks of culture, rAT-MSCs in the adipogenic differentiation cocktail developed enlarged lipid droplets that invaded the entire cytoplasm of each cell. Their differentiation into adipocytes was confirmed by Oil Red O staining (Supplementary Data 1). Moreover, the cells cultured in the osteogenic differentiation medium formed cellular aggregates that were characterized by the presence of amorphous material deposits. The amorphous deposits were observed under a microscope and stained with Alizarin red S to confirm that they were calcium deposits (Supplementary Data 1). The neurogenic differentiation of isolated cells was observed in 5-day-old culture media that included a chemical cocktail. Neuron-like cells displayed distinct morphologies that ranged from extensively simple, bipolar cells to large, branched and multipolar cells. These cells positively stained for some neuron or glial cell-specific markers, including nestin, c-Fos, GFAP and $\beta 3$-tubulin (Supplementary Data 2).

\section{Analysis of the Injury Epicenter}

Hematoxylin and eosin staining of the longitudinal sections of the spinal cord at the $28^{\text {th }}$ day p.i. showed serious lesions, including the loss of some tissue parts, in the untreated groups (Groups 3 and 5). PHS injection directly after injury did not improve the tissue integrity significantly at the injury epicenter. At the same stage, during which rAT-MSCs were injected instead of PHS, regeneration improved in the $\mathrm{L}+\mathrm{T}+\mathrm{MSC} /$ acute group (Figure 1). Interestingly, the tissue integrity seemed to be enhanced by MSC injection on the $9^{\text {th }}$ day p.i. The injury epicenter was also limited in the $L+T+P H S /$ subacute group. Nevertheless, axonal regeneration was only noticeable in the rAT-MSC-transplanted groups, particularly in the $\mathrm{L}+\mathrm{T}+\mathrm{MSC} /$ subacute group (Figure 1).

\section{Apoptotic Cells}

TUNEL staining was performed to determine the number of apoptotic cells. The laminectomy did not increase the number of apoptotic cells significantly (Figures 2, 3 and Table I). In contrast, trauma induction via laminectomy resulted in an increased number of TUNEL-positive cells. PHS injection into the lesion site during the acute period did not improve this state. Although the mean number of apoptotic cells decreased, this change was not significant. However, the number of TUNELpositive cells was significantly lower in rAT-MSCs group at the lesion site of the spinal cord than $L+T$ group (Figure 2). The substantial decrease in the number of apoptotic cells was also supported by the histological analysis of the tissue sections (Figures 1 and 3). rAT-MSC transplantation at the subacute phase, during which inflammation was reduced in the lesion, did not have any distinct effect.

\section{Neuronal Regeneration and Paracrine Effects of rAT-MSCs}

GFP and vimentin immunostaining of the sections was used to observe the infiltration of rAT-MSCs into the lesion sites (Figure 4). In contrast to the groups receiving rAT-MSC transplants, the control groups that received PHS injections showed no binding against GFP and vimentin antibodies. Although the lesion site seemed to be largely deteriorated in both groups, the groups receiving rAT-MSC transplants had smaller cell-free regions (cavities), which might indicate tissue regeneration (Figure 4). Moreover, the lesion epicenter was surrounded by GFP-positive rAT-MSCs, and the number of these cells differed. The tissue treated with rAT-MSCs during the acute phase had fewer GFP-positive cells after 28 days than the tissue treated during the subacute phase. This finding may be associated with the hostile conditions of the tissue induced by inflammation after injury. During the subacute phase ( 9 days p.i.), the inflammation was greatly reduced; therefore, the environment was less hostile to the transplanted rAT-MSCs.
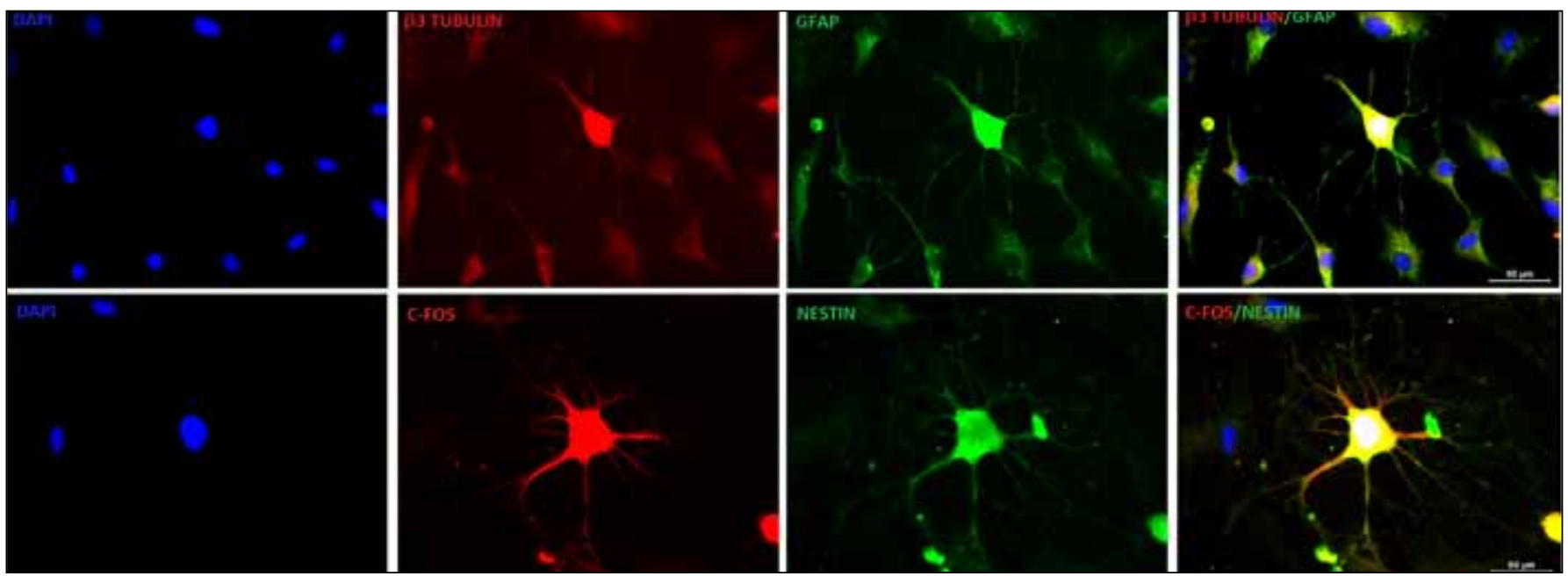

Supplementary Data 2: Expression of neural markers by rAT-SCs after differentiation. Differentiated cells represented intensified staining of GFAP (green) and beta 3-Tubulin (red); nestin (green) and cFos (red) (Scale bars: $50 \mu \mathrm{m})$. 
The spinal cord tissue sections were assessed by immunoreac-tivity against some important neuronal markers. To identify the neurons and to separate them from glial cells, the tissue sections were stained against $\beta 3$-tubulin (Figure 5). SCI caused a series of time-dependent structural and physiological changes at the trauma site, which also triggered the regeneration process. Anti- $\beta 3$-tubulin staining of the tissue sections from the PHS-injected acute group was not as strong as in the sections from the PHS-injected subacute group (Figure 5). The transplantation of stem cells improved the regeneration of the neuronal cell network. A remarkable increase in $\beta 3-$ tubulin staining was observed in the rAT-MSCs/acute group compared to the PHS/acute group, and the strongest binding of anti- $\beta 3$-tubulin was observed in the rAT-MSCs/subacute group (Figure 5). Because $\beta 3$-tubulin is a specific marker of neurons in the spinal cord tissue, the different expression levels in the tissue sections might indicate different stages of neural regeneration.

The expression of some important neutrophic factors was analyzed in the tissue to understand the effects of rAT-MSC transplantation on SCI. For this purpose, we focused on BDNF and CNTF, which primarily support axonal outgrowth and neuronal cell survival, respectively. BDNF expression is particularly important in the axonal outgrowth of neurons. Following injury, the effects of BDNF are extensively important to neuron regeneration, although this neurotrophic factor is insufficient to rescue the survival of neuronal cells. Thus, the expression of CNTF by rAT-MSCs in the lesion site p.i. is important for the survival of neuronal cells. In all groups, detectable levels of BDNF were expressed in the lesion sites p.i. (Figure 6). The number of BDNF-positive cells and the intensity of the BDNF staining were significantly higher in the treatment groups. The reduced size of the cavities (cell-free regions) on the spinal cord within the groups receiving stem cell transplants may be explained by the expression levels of BDNF in rAT-MSCs. However, CNTF was expressed only by the GFP+ rAT-MSCs in the tissues (Figure 7). Together with BDNF, CNTF may regulate the regeneration process without scar tissue formation. The transplantation time, whether during the acute or subacute phase, did not have any considerable effect.

CNPase-positive cells infiltrated the spinal cords of the PHStreated subacute group but not those of the $\mathrm{L}+\mathrm{T}+\mathrm{PHS} /$ acute group (Figure 8). After the inflammation decreased following injury, PHS injection positively induced the migration of oligodendrocytes into the spinal cord, which improved the regeneration process. The number of CNPase-positive cells was considerably higher in the stem cell-treated groups (Figure 8). The double staining of cells with both GFP and CNPase may indicate that some of the rAT-MSCs differentiated into oligodendrocytes. Infiltration and differentiation were not limited to the epicenter of the lesion (star) but were observed throughout the tissue.

\section{Functional Recovery}

To confirm the traumatic impact of the standardized severe injury to the T10-T11 spinal cord, we evaluated hind limb locomotion in the $\mathrm{SCl}$ rats. Before injury, the rats showed

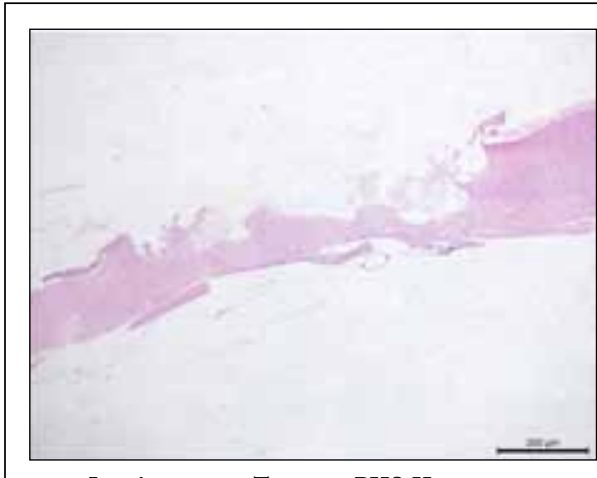

Laminectomy+Trauma+PHS-Hyperacute

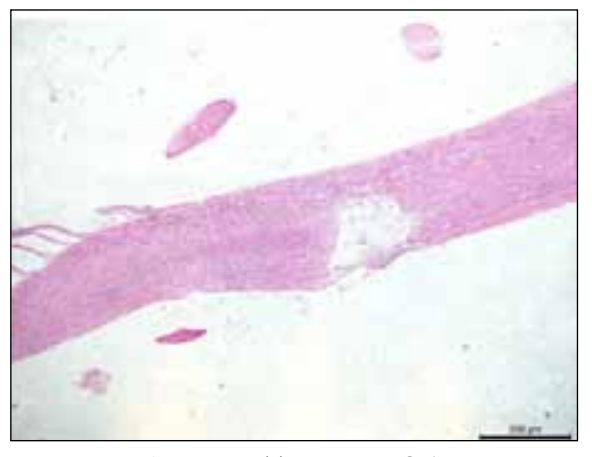

Laminectomy+Trauma+PHS-Acute

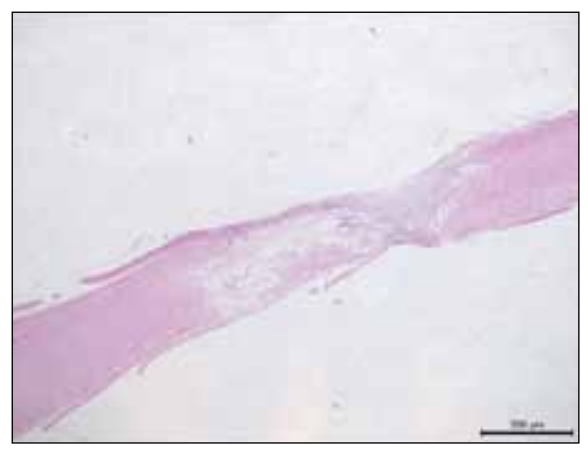

Laminectomy+Trauma+rAT-SCs-Hyperacute

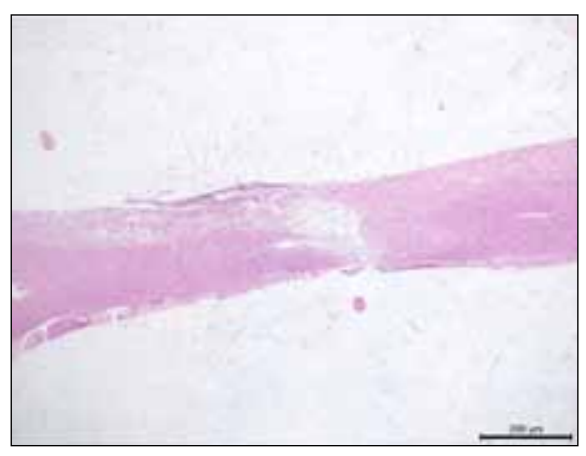

Laminectomy+Trauma+rAT-SCs-Acute
Figure 1: Hematoxylin staining of representative $5-\mu \mathrm{m}$ thick longitudinal sections from the control and experimental groups at 28 p.i. Despite the degeneration in the $\mathrm{L}+\mathrm{T}+\mathrm{PHS} /$ acute group, preserved tissue was observed near the injury epicenter, as well as rostrally and caudally from the injury. Stem cell transplantation at the lesion site during the acute phase ( $\mathrm{L}+\mathrm{T}+\mathrm{MSC}$ /acute group) substantially improved the damage. During the subacute phase $(\mathrm{L}+\mathrm{T}+\mathrm{PHS} /$ subacute group), PHS injection at the lesion site, in which the injection was performed at 9 days p.i., also improved the damage in the $L+T+M S C s / a c u t e$ group. The regeneration in the $\mathrm{L}+\mathrm{T}+\mathrm{MSCs} /$ subacute group was more advanced than in the other groups. Scale bar, 200 $\mu \mathrm{m}$. 

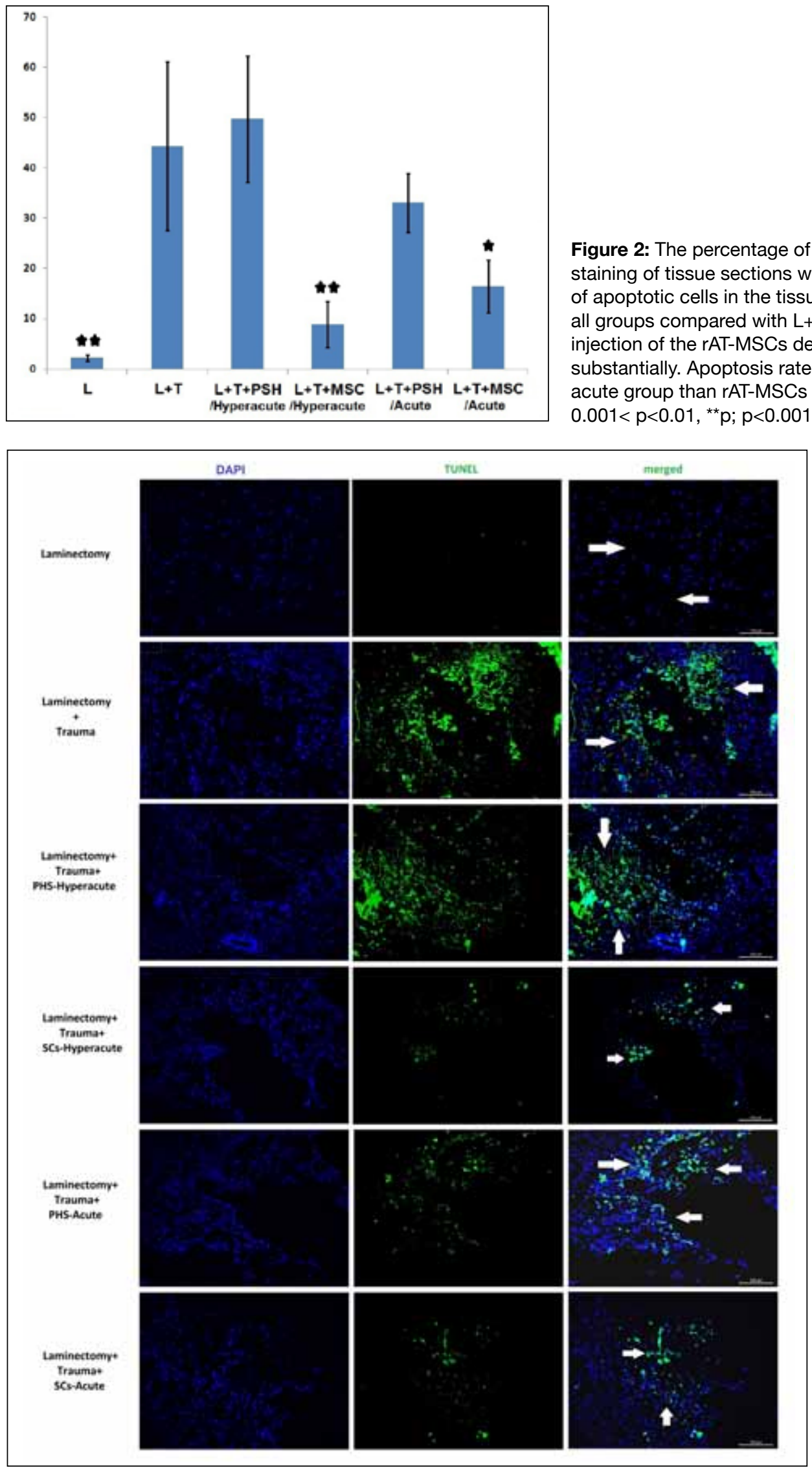

Figure 2: The percentage of apoptotic cells at 28 days p.i. TUNEL staining of tissue sections was performed to determine the number of apoptotic cells in the tissue sections from the groups. Statistically all groups compared with L+T group; we observed that the injection of the rAT-MSCs decreased the number of apoptotic cells substantially. Apoptosis rate was significantly lower at rAT-MSCs acute group than rAT-MSCs subacute group. $\left(0.01<p<0.05,{ }^{*} p\right.$; $\left.0.001<p<0.01,{ }^{* \star} p ; p<0.001,{ }^{\star * *} p\right)$.
Figure 3: Tunel staining was performed to demonstrate apoptotic cells in the groups. Apoptotic cells were not observed in Laminectomy group, much apoptotic cell density was determined in Laminectomy+Trauma and Laminectomy+Trauma+PHS-Acute groups. The apoptotic cell density of Laminectomy+Trauma+SCsAcute group was observed less than the Laminectomy+Trauma +SCsSubacute group. The nucleus of cells was stained with DAPI (blue) (Scale bars: $50 \mu \mathrm{m})$. 
no functional deficits in motor behavior and thus were given the highest BBB score of 21 . In all rats, the laminectomy and trauma caused flaccid hindlimb paralysis with a BBB score of 0 . At each assessment time point, consistent functional deficits were noted among the $\mathrm{SCl}$ rats, with the BBB locomotion

Table I: $\mathrm{P}$ Values of All Groups Compared with $\mathrm{L}+\mathrm{T}$ Group and Hyperacute-Acute Groups Compared with Each Other $(0.01<$ $\left.p<0.05,{ }^{\star} p ; 0.001<p<0.01,{ }^{\star \star} p ; p<0.001,{ }^{\star \star \star} p\right)$

\begin{tabular}{lll}
\hline Groups & p value & \\
\hline L+T \& L & 0.004 & $* *$ \\
\hline L+T \& L+T+PSH/Hyperacute & 0.58 & - \\
\hline L+T \& L+T+MSC/Hyperacute & 0.007 & $* *$ \\
\hline L+T \& L+T+PSH/Acute & 0.21 & - \\
\hline L+T \& L+T+MSC/Acute & 0.017 & $*$ \\
\hline L+T+PSH/Hyperacute \& L+T+MSC/ & 0.0010 & $* *$ \\
Hyperacute & & \\
\hline L+T+PSH/Acute \& L+T+MSC/Acute & 0.0014 & $* *$ \\
\hline
\end{tabular}

scores showing initial profound losses that gradually improved, approaching a plateau level of spontaneous recovery by 4 weeks p.i. that is typical for this type of injury (1). Over the following 4 weeks, a gradual recovery of hindlimb locomotion was observed in all rats. However, the rate of recovery of the rats in the stem cell transplant groups was remarkably faster than in the rats of all other groups. No significant differences were observed between the two groups in which the rATMSCs were transplanted during the acute or subacute phases of injury. Furthermore, the performances of the $L+T+M S C /$ acute group differed significantly compared to the $L+T$ and $\mathrm{L}+\mathrm{T}+\mathrm{PHS} /$ acute groups at days $7,14,21$, and 28 p.i. $(p<0.05$; Figure 9). Moreover, the performances of the $L+T+M S C /$ subacute group differed significantly compared to the $L+T$ and $L+T+P H S /$ subacute groups at days $7,14,21$, and 28 p.i. $(p<0.05$; Figure 9$)$. The injured rats $(\mathrm{L}+\mathrm{T}$ group and $\mathrm{L}+\mathrm{T}+\mathrm{PHS} /$ subacute group) showed marked deficits which persisted through the duration of the study.

\section{DISCUSSION}

MSC therapies have proven to be successful in many $\mathrm{SCl}$ studies. Many alternative sources for the isolation of MSCs

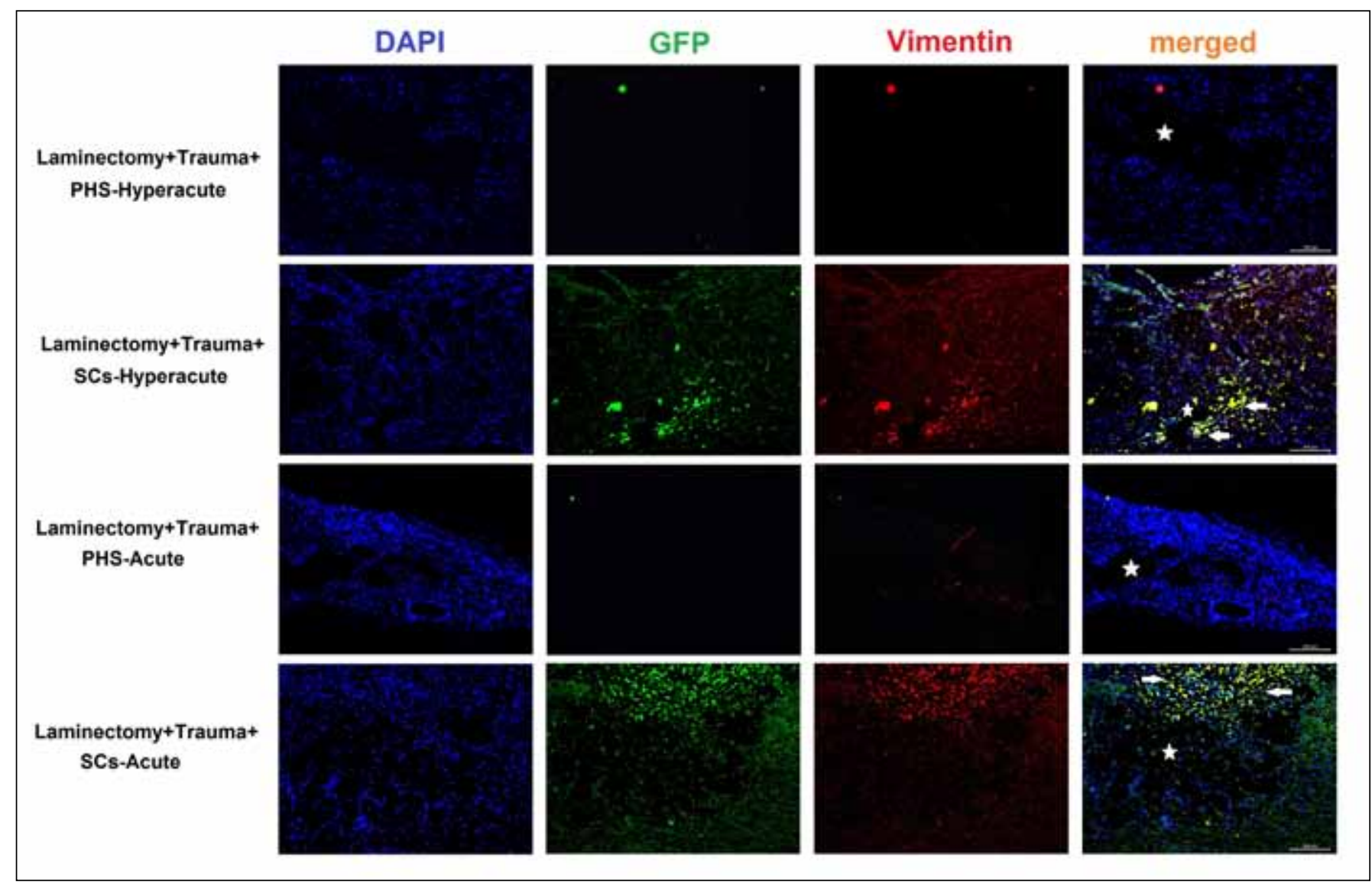

Figure 4: The infiltration of rAT-MSCs into the lesion site. The stem cells transplanted into the spinal cord were labeled previously with GFP. Vimentin was used as an MSC marker and was used along with GFP to track the rAT-MSCs in the tissue. The GFP/vimentin-positive cells (arrows) collected around the lesion site (star) in the rAT-MSC-transplanted tissues at 28 days p.i. Between the different treatment groups, large differences in the number of cells at this location were observed. In the MSC group transplanted during the subacute phase, a greater number of cells could be observed than in the MSC group transplanted during the acute phase. Scale bar, $200 \mu \mathrm{m}$. 


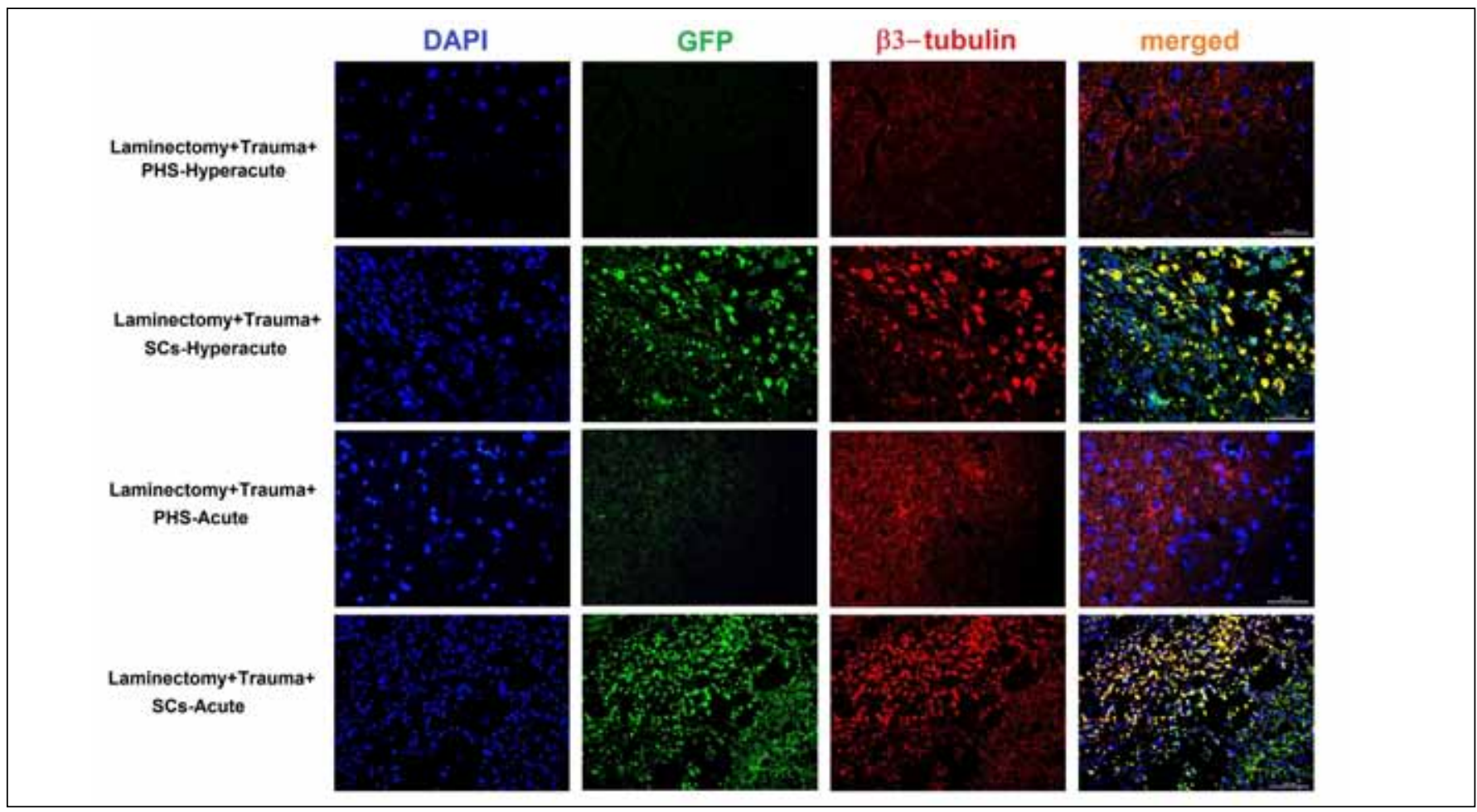

Figure 5: The immunostaining of longitudinal sections of rat spinal cords for $\beta 3$-tubulin expression. Because $\beta 3$-tubulin is a specific marker of neurons in the spinal cord, its different expression levels in the tissue sections may indicate neuronal regeneration. In the PHSinjected groups, $\beta 3$-tubulin expression was weak. By contrast, the stem cell-transplanted groups demonstrated strong staining patterns indicating that the rAT-MSCs might be directly involved in differentiation-meditated regeneration. Scale bar, $50 \mu \mathrm{m}$.

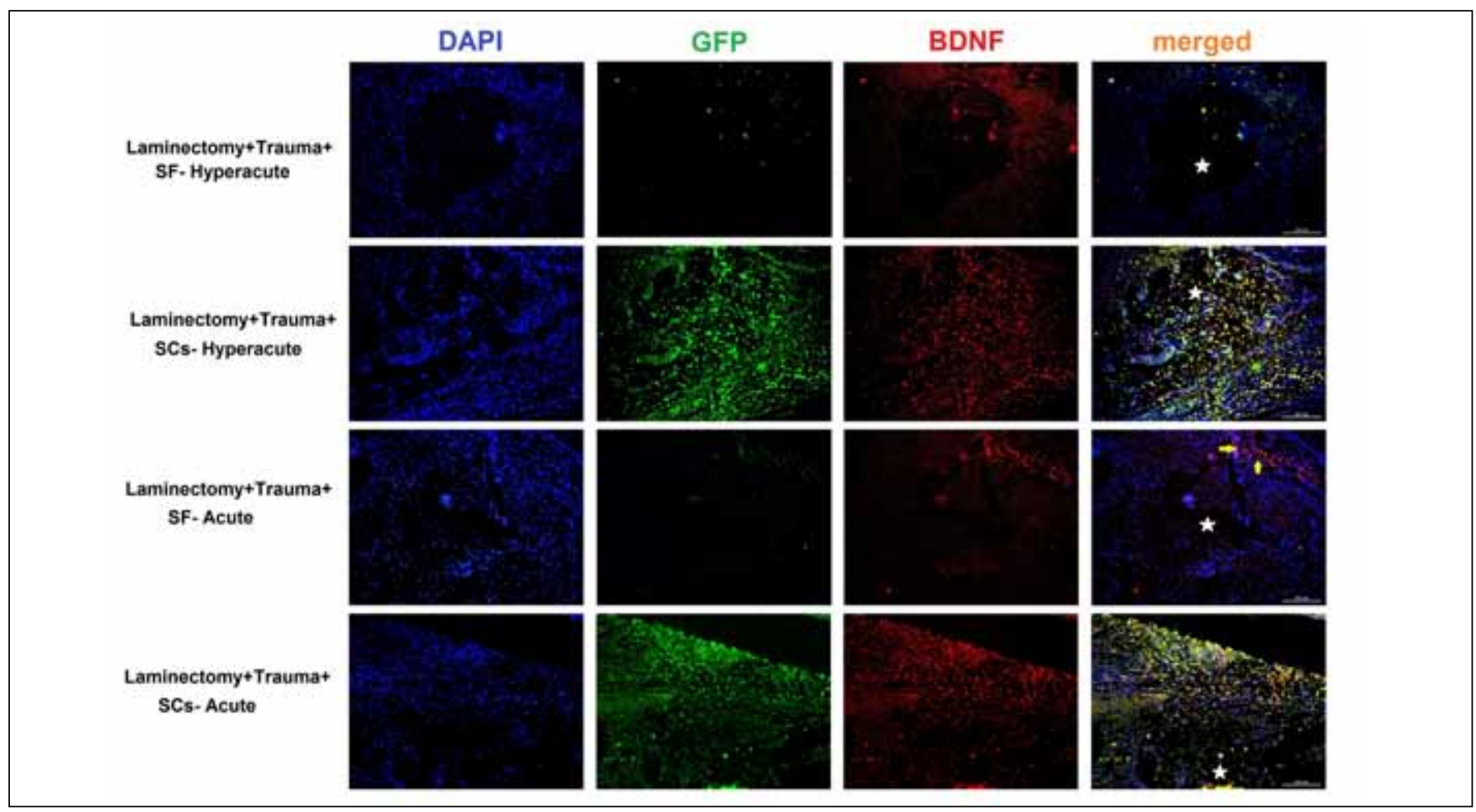

Figure 6: Detection of BDNF in the SCI lesion site. The expression of this neurotrophic factor was induced in the tissue by the signals derived p.i. The expression level of BDNF was limited in the PHS-injected groups. By contrast, the expression of BDNF by GFP-positive rAT-MSCs near the lesion epicenter (star) increased significantly, which might support axonal outgrowth (Scale bar, $200 \mu \mathrm{m})$. 


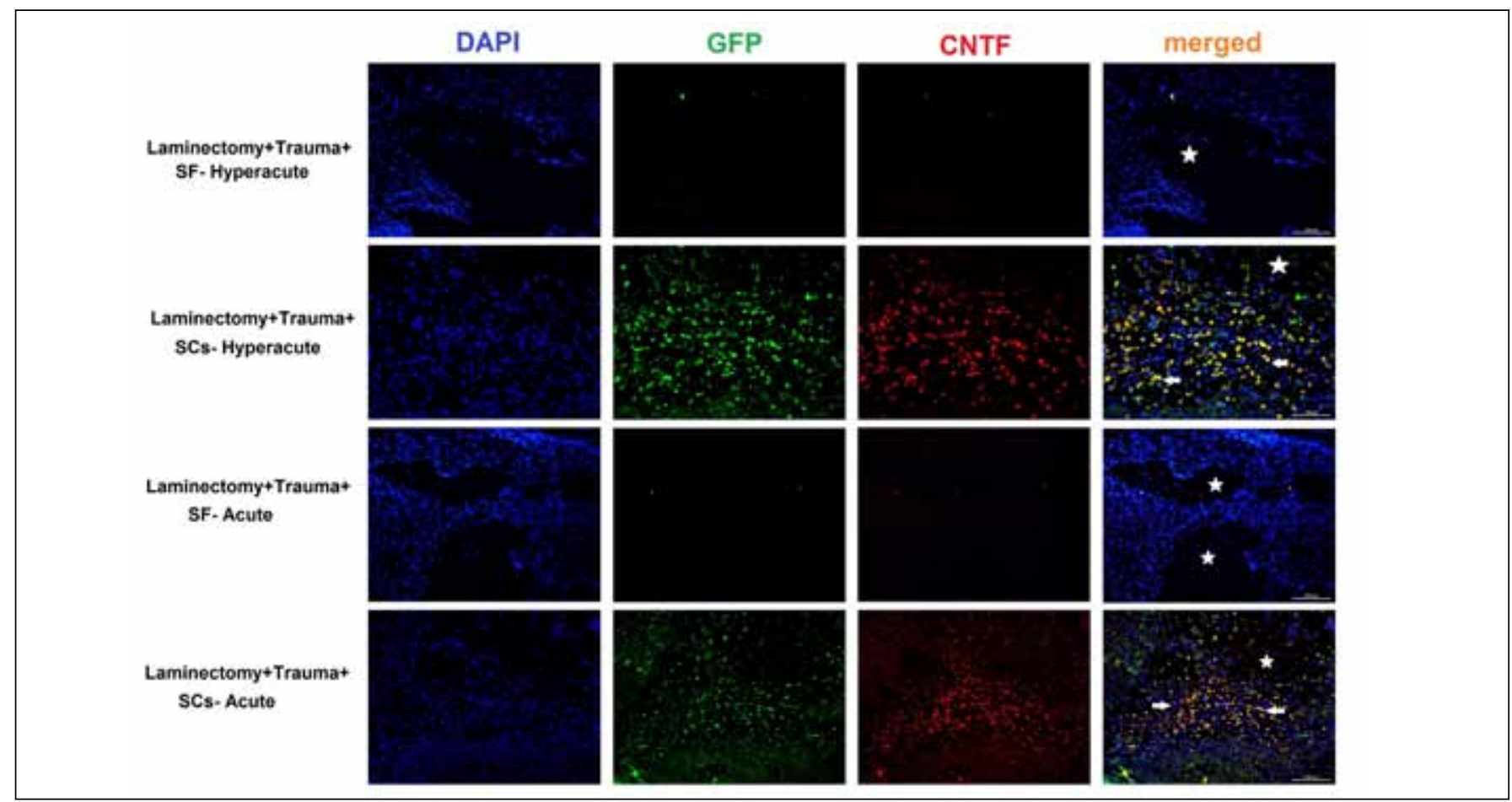

Figure 7: The CNTF expression by rAT-MSCs in the tissue at 28 days p.i. The expression was only observed in the spinal cords receiving transplanted GFP-positive rAT-MSCs. CNTF may be involved in the improvement of the survival rate of neuronal cells after SCI. The difference in the number of CNTF-positive cells (arrows) between the two stem cell-treated groups was insignificant. The host-originated expression of CNTF was not observed in the control groups, which may explain why the expression did not surround the epicenter of the lesion (stars) but was limited to the location of the stem cell injection (Scale bar, $200 \mu \mathrm{m}$ ).

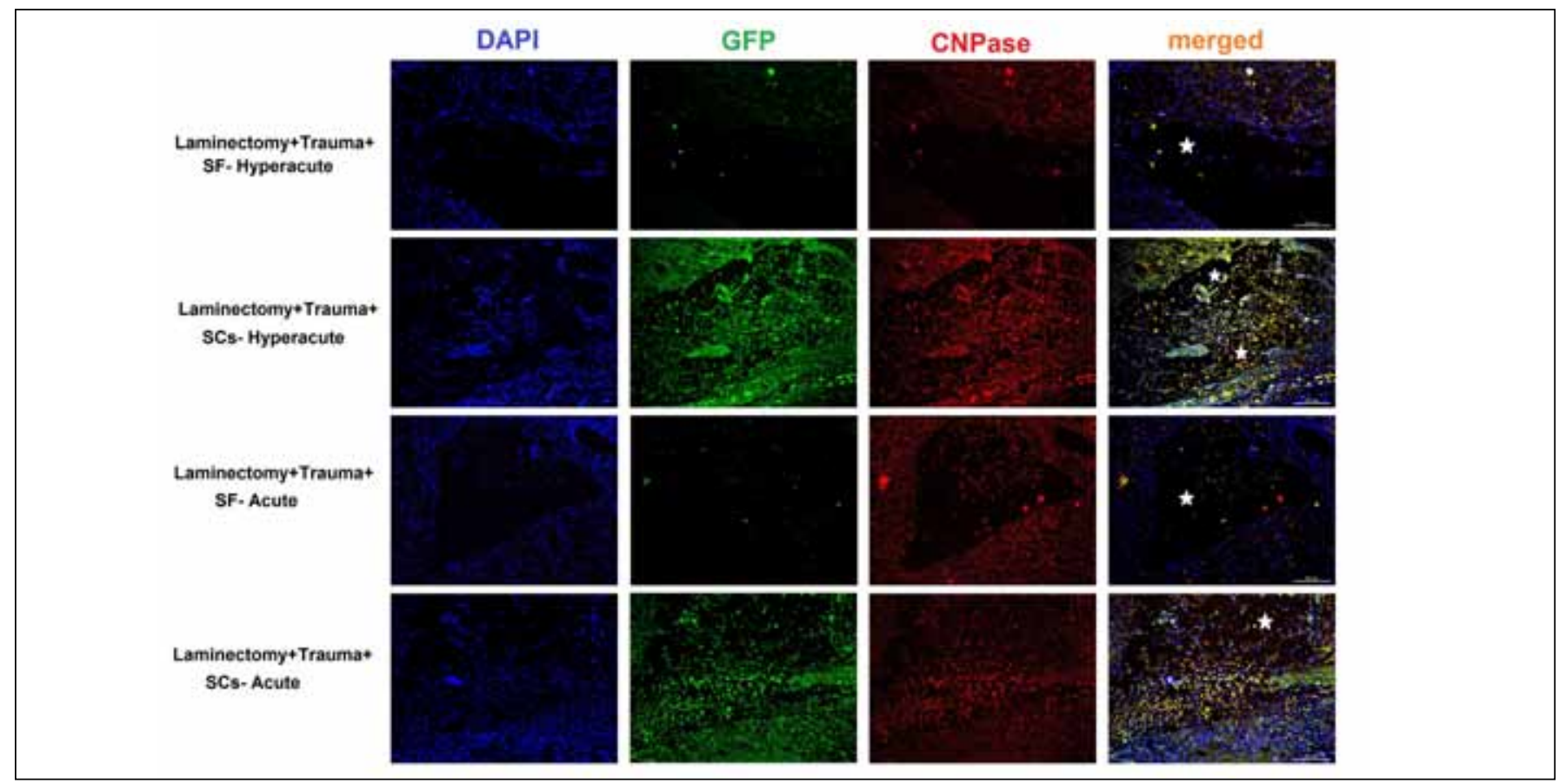

Figure 8: CNPase-expressing cells in the trauma site after SCI. CNPase is a mature oligodendrocyte marker, and CNPase-positive cells in tissues may indicate the infiltration of oligodendrocytes into the injury site. In the L+T+PHS/acute group, CNPase-positive cell infiltration was not observed, but these cells were observed in the tissues in the L+T+PHS/subacute group. The stem cell-treated groups all showed increased numbers of CNPase-positive cells in the spinal cord arising from infiltration by oligodendrocytes and the differentiation of GFP-positive rAT-MSCs into oligodendrocytes (Scale bar, $200 \mu \mathrm{m}$ ). 
exist, and depending on the origin, these cells can show small differences that may have great effects on the disease treatment. In this study, rAT-MSCs were isolated, characterized and used in the treatment of SCl. The effectiveness of the treatment strategies, i.e., injections during the acute and subacute phases, was compared. Adipose tissue-derived stem cells have been shown to differentiate into oligodendrocytes, which participate in the functional recovery of $\mathrm{SCl}$ in rat models (12). In the lesion sites of the groups receiving stem cell transplants, we detected $\beta 3$-tubulin expression in the GFP-positive cells. The application of stem cells during the acute or subacute phase following $\mathrm{SCl}$ affected the number of $\beta 3$-tubulin-positive cells. Our in-vitro studies were showed that rAT-MSC can be differentiated to neuronal cell types. After injection of undifferentiated GFP+rAT-MSCs to SCl rats, it was observed expression of both GFP+ and b3-tubulin in paraffin sections of SCl-MSC groups. In-vivo experiments, the neuronal differentiation of rAT-MSCs is thought to be through the signals of microenvironment of injured spinal cord or microvesicular transfer. More recently, it has been shown that MSCs could differentiated under the stimulation of microvesicle which are secreted by injured cells (8). Although the differentiation of rAT-MSCs into neurogenic cell lines has been shown to be inadequate for functional recovery, rATMSC cell extracts have been demonstrated to inhibit hydrogen peroxide-mediated apoptosis, thereby preventing the adverse effects of hostile conditions at the lesion site $(13,23)$.

The activities of both CNTF and CNPase together improved the survival rate, but the time of injection (acute or subacute) became insignificant. The number of apoptotic cells decreased in the groups receiving stem cell transplants. In this case, the differences between injection during the acute and subacute phases also became insignificant. The slightly higher number of $\beta 3$-tubulin-positive cells in the lesion site may have also affected the BBB scoring of the $L+T+M S C /$ acute and $\mathrm{L}+\mathrm{T}+\mathrm{MSC} /$ subacute groups.

The expression of neurotrophic factors and paracrine effects may have potential uses in recovery after SCl. In a previous study, Sasaki et al. (24) used genetically improved cell lines to secrete BDNF in the treatment of $\mathrm{SCl}$. The overexpression of BDNF in the tissue environment caused structural changes in the brain and spinal cord; these structural changes were associated with improved functional outcomes in subacute $\mathrm{SCl}$. Although BDNF is known to be involved in axonal outgrowth during the regeneration process, it was not shown to have a significant effect on cell survival (16). Thus, CNTF may play a role in increasing the number of viable cells in the tissue. CNTF has been shown to support the survival of neurons p.i. by activating the JAK-STAT pathway (22). In this study detectable levels of BDNF in the lesion site were expressed in all groups. However CNTF were expressed only in GFP+ Rat-MSCs groups. Winter et al. (28) showed some confusing data indicating that a CNTF overdose might induce GFAP expression and might cause scar tissue formation during early stages following injury. However, the critical level of CNTF required for scar tissue formation was not defined, and in the presence of other factors such as BDNF, CNTF has the potential to prevent scar tissue formation.

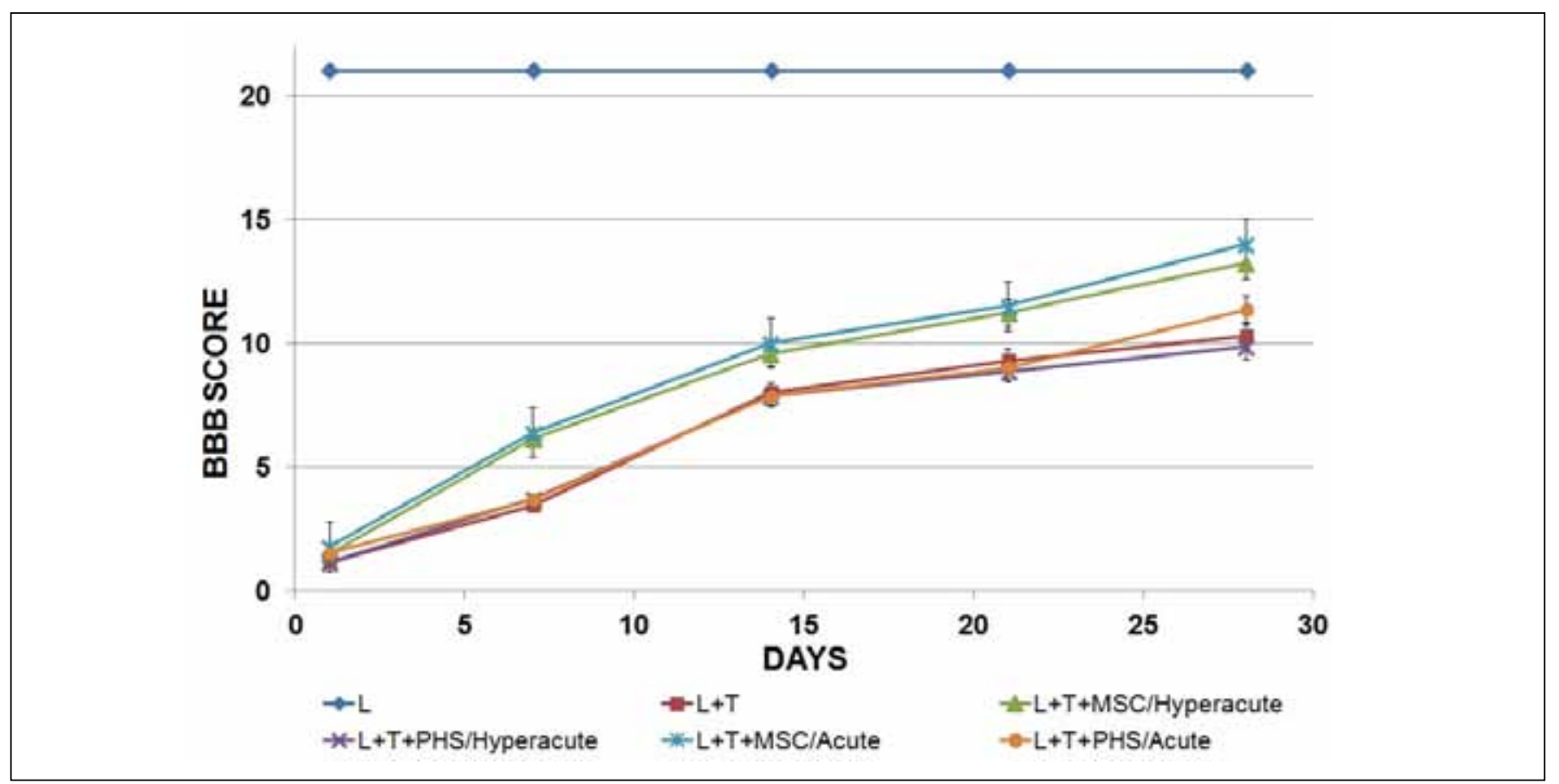

Figure 9: BBB scoring. The functional recovery of $\mathrm{SCl}$ in the model animals was evaluated by the motor functions of the rats. The animals were separated randomly into six groups [laminectomy $(\mathrm{L})$, laminectomy+trauma $(\mathrm{L}+\mathrm{T})$, laminectomy+trauma+PHS/acute ( $\mathrm{L}+\mathrm{T}+\mathrm{PHS} /$ acute), laminectomy+trauma+MSCs/acute ( $\mathrm{L}+\mathrm{T}+\mathrm{MSCs} /$ acute), laminectomy+trauma+PHS/subacute ( $\mathrm{L}+\mathrm{T}+\mathrm{PHS} / \mathrm{subacute})$, and laminectomy+trauma+MSCs/subacute ( $\mathrm{L}+\mathrm{T}+\mathrm{MSCs} /$ subacute)) and were assessed according to the open field locomotor scale. A gradual recovery of hindlimb locomotion was observed in all rats over the following 4 weeks. 
The expression of CNPase, an oligodendrocyte marker, increased substantially in the lesion site of the groups receiving stem cell transplants. As suggested by Steffenhagen et al. (24) the transdifferentiation of the rAT-MSCs used in our study into oligodendrocytes might play a crucial role in regeneration after SCl. Remyelination by MSCs after SCl considerably improved the SCl regardless of whether the rAT-MSCs were applied during the acute or subacute phase. Increased levels of CNPase in the spinal cords are considered important for the long-term survival of white matter tissue (7).

The locomotor activity of the rats in the stem cell-treated groups was noticeably improved, and whether the transplantation occurred during the acute or subacute phases had little apparent effect on the functional recovery. During the acute phase, neuronal necrosis, axonal disruption, blood supply insufficiency, edema and excitotoxic neurotransmitters are triggered. These changes continue into the subacute phase, during which ischemia, oxidative stress, lipid peroxidation and inflammation predominate $(9,15,17,25)$. In this study, the effects of transplanting rAT-MSCs immediately (acute) and 9 days (subacute) p.i. were reported. Although the environment was hostile to the transplanted cells during both the acute and subacute phases, the outcome of this study demonstrated that rAT-MSCs can successfully survive in these environments and are involved in the functional recovery following $\mathrm{SCl}$.

\section{- CONCLUSION}

MSCs have been shown to modulate many of the detrimental effects associated with acute damage in $\mathrm{SCl}$ by neuronal protection and inflammation suppression, as well as the secretion of multiple factors that modulate neuronal growth, and the reduction of cavity formation $(26,27)$.

The transplantation of MSCs derived from different tissues improved the locomotor recovery following $\mathrm{SCl}$, and the capacity of rAT-MSCs to differentiate into the oligodendrocyte lineage improved the functional recovery. An important point of this study was the determination of the ideal transplantation time. The results revealed that the local conditions at the time of the transplantation were important for the cell behavior. From the perspective of functional recovery following $\mathrm{SCl}$, the transplantation of rAT-MSCs into the lesion site during the acute or subacute phases did not differ significantly at 28 days p.i. Additionally, whether the small differences between these groups, such as the number of $\beta 3$-tubulin-positive cells, might affect the long-term functionality of the spinal cord, was unclear.

\section{- REFERENCES}

1. Arboleda D, Forostyak S, Jendelova P, Marekova D, Amemori $\mathrm{T}$, Pivonkova $\mathrm{H}$, Masinova K, Sykova $\mathrm{E}$ : Transplantation of predifferentiated adipose-derived stromal cells for the treatment of spinal cord injury. Cell Mol Neurobiol 31: 1113-1122, 2011

2. Basso DM, Beattie MS, Bresnahan JC: A sensitive and reliable locomotor rating scale for open field testing in rats. J Neurotrauma 12: 1-21, 1995
3. Bourin P, Bunnell BA, Casteilla L, Dominici M, Katz AJ, March KL, Redl H, Rubin JP, Yoshimura K, Gimble JM: Stromal cells from the adipose tissue-derived stromal vascular fraction and culture expanded adipose tissue-derived stromal/stem cells: A joint statement of the International Federation for Adipose Therapeutics and Science (IFATS) and the International Society for Cellular Therapy (ISCT). Cytotherapy 15(6):641-648, 2013

4. Cakici C, Buyrukcu B, Duruksu G, Haliloglu AH, Aksoy A, Isık A, Uludag $O$, Ustun $\mathrm{H}$, Subası C, Karaoz E: Recovery of fertility in azoospermia rats after injection of adipose-tissue-derived mesenchymal stem cells: The sperm generation. Biomed Res Int 2013:529589, 2013

5. Choi H, Liao WL, Newton KM, Onario RC, King AM, Desilets FC, Woodard EJ, Eichler ME, Frontera WR, Sabharwal S, Teng YD: Respiratory abnormalities resulting from midcervical spinal cord injury and their reversal by serotonin $1 \mathrm{~A}$ agonists in conscious rats. J Neurosci 25(18): 4550-4559, 2005

6. Dasari VR, Veeravalli KK, Dinh DH: Mesenchymal stem cells in the treatment of spinal cord injuries: A review. World J Stem Cells 6:120-33, 2014

7. Ek CJ, Habgood MD, Dennis R, Dziegielewska KM, Mallard C, Wheaton B, Saunders NR: Pathological changes in the white matter after spinal contusion injury in the rat. PLoSOne $7(8)$ e43484, 2012

8. Gosselin RD, Meylan P, Decosterd I: Extracellular microvesicles from astrocytes contain functional glutamate transporters: Regulation by protein kinase $\mathrm{C}$ and cell activation. Front Cell Neurosci10; 7:251, 2013

9. Gorgulu A, Kiris T, Unal F, Turkoglu U, Kucuk M, Cobanoglu S: Superoxide dismutase activity and the effects of NBQX and CPP on lipid peroxidation in experimental spinal cord injury.Res Exp Med (Berl) 199(5):285-293, 2000

10. Kabatas S, Teng YD: Potential roles of the neural stem cell in the restoration of the injured spinal cord: Review of the literature. Turk Neurosurg 20(2):103-110, 2010

11. Kamei N, Tanaka N, Oishi Y, Ishikawa M, Hamasaki T, Nishida K, Nakanishi K, Sakai N, Ochi M: Bone marrow stromal cells promoting corticospinal axon growth through the release of humoral factors in organotypic cocultures in neonatal rats. $J$ Neurosurg Spine 6(5):412-419, 2007

12. Kang SK, Shin MJ, Jung JS, Kim YG, Kim CH: Autologous adipose tissue-derived stromal cells for treatment of spinal cord injury. Stem Cells Dev 15:583-594, 2006

13. Kang SK, Yeo JE, Kang KS, Phinney DG: Cytoplasmic extracts from adipose tissue stromal cells alleviates secondary damage by modulating apoptosis and promotes functional recovery following spinal cord injury. Brain Pathol 17:263-275, 2007

14. Karaoz E, Aksoy A, Ayhan S, Sariboyaci AE, Kaymaz F, Kasap $M$ : Characterization of mesenchymal stem cells from rat bone marrow: Ultrastructural properties, differentiation potential and immunophenotypic markers. Histochem Cell Biol 132: 533-546, 2009

15. Karaoz E, Kabatas S, Duruksu G, Okcu A, Subasi C, Ay B, Musluman M, Civelek E: Reduction of lesion in injured rat spinal cord and partial functional recovery of motility after bone marrow derived mesenchymal stem cell transplantation. Turk Neurosurg 22(2):207-217, 2012

16. Lindsay RM: Nerve growth factors (NGF, BDNF) enhance axonal regeneration but are not required for survival of adult sensory neurons. J Neurosci 8:2394-2405, 1988 
17. Neirinckx V, Cantinieaux D, Coste C, Rogister B, Franzen R, Wislet-Gendebien S: Concise review: Spinal cord injuries: How could adult mesenchymal and neural crest stem cells take up the challenge? Stem Cells 32:829-843, 2014

18. Oh JS, Park IS, Kim KN, Yoon DH, Kim SH, Ha Y: Transplantation of an adipose stem cell cluster in a spinal cord injury. Neuroreport 23:277-282, 2012

19. Park SS, Lee YJ, Lee SH, Lee D, Choi K, Kim WH, Kweon OK, Han $\mathrm{HJ}$ : Functional recovery after spinal cord injury in dogs treated with a combination of Matrigel and neural-induced adiposederived mesenchymal Stem cells. Cytotherapy 14:584-597, 2012

20. Parr AM, Kulbatski I, Wang $\mathrm{XH}$, Keating $\mathrm{A}$, Tator $\mathrm{CH}$ : Fate of transplanted adult neural stem/progenitor cells and bone marrowderived mesenchymal stromal cells in the injured adult rat spinal cord and impact on functional recovery. SurgNeurol 70: 600-607, 2008

21. Parr AM, Kulbatski I, Zahir T, Wang X, Yue C, Keating A, Tator $\mathrm{CH}$ : Transplanted adult spinal cord-derived neural stem/progenitor cells promote early functional recovery after rat spinal cord injury. Neuroscience 155: 760-770, 2008

22. Peterson WM, Wang Q, Tzekova R, Wiegand SJ: Ciliary neurotrophic factor and stress stimuli activate the Jak-STAT pathway in retinal neurons and glia. J Neurosci 20:4081-4090, 2000

23. Ryu HH, Lim JH, Byeon YE, Park JR, Seo MS, Lee YW, Kim WH, Kang KS, Kweon OK: Functional recovery and neural differentiation after transplantation of allogenic adipose-derived stem cells in a canine model of acute spinal cord injury. $J$ Vet Sci 10:273-284, 2009
24. Sasaki M, Radtke C, Tan AM, Zhao P, Hamada H, Houkin $\mathrm{K}$, Honmou O, Kocsis JD: BDNF-hypersecreting human mesenchymal stem cells promote functional recovery, axonal sprouting, and protection of corticospinal neurons after spinal cord injury. J Neurosci 29:14932-4941, 2009

25. Sonmez E, Kabatas S, Ozen O, Karabay G, Turkoglu S, Ogus E, Yilmaz C, Caner H, Altinors N: Minocycline treatment inhibits lipid peroxidation, preserves spinal cord ultrastructure, and improves functional outcome after traumatic spinal cord injury in the rat. Spine (Phila Pa1976) 38(15):1253-1259,2013

26. Steffenhagen C, Dechant FX, Oberbauer E, Furtner T, Weidner N, Küry P, Aigner L, Rivera FJ: Mesenchymal stem cells prime proliferating adult neural progenitors toward an oligodendrocyte fate. Stem Cells Dev 21:1838-1851, 2012

27. Teng YD, Yu D, Ropper AE, Li J, Kabatas S, Wakeman DR, Wang J, Sullivan MP, Redmond DE Jr, Langer R, Snyder EY, Sidman $\mathrm{RL}$ : Functional multipotency of stem cells: A conceptual review of neurotrophic factor-based evidence and its role in translational research. Curr Neuropharmacol 9(4):574-585, 2011

28. Winter CG, Saotome Y, Levison SW, Hirsh D: A role for ciliary neurotrophic factor as an inducer of reactive gliosis, the glial response to central nervous system injury. Proc Natl Acad Sci U S A 92:5865-5869, 1995

29. Zaminy A, Shokrgozar MA, Sadeghi Y, Norouzian M, Heidari MH, Piryaei A: Transplantation of schwann cells differentiated from adipose stem cells improves functional recovery in rat spinal cord injury. Arch Iran Med16:533-541, 2013 